\title{
Optimization of Growth Hormone Therapy in Growth Hormone Deficient Children
}

\author{
De Muinck Keizer-Schrama S.M.P.F. \\ Department of Pediatrics, Subdivision Endocrinology, Erasmus University and University \\ Hospital, Rotterdam/Sophia Children's Hospital, The Netherlands
}

\section{Earlier Studies}

Successful treatment with human growth hormone $(\mathrm{hGH})$ was initially reported by Raben in $1958^{1}$. Although it is well established that pituitary derived or biosynthetic $\mathrm{hGH}$ increases the growth rate in growth hormone deficient children, many patients that were treated in the early days have not reached their target height, or attained adult height below the thind percentile of population standards ${ }^{2-}$ 5 . Several explanation have been suggested for these disappointing results. In the earlier days treatment was started at a rather late age and therefore a substantial growth potential has been lost already. Several investigators found positive correlation between final height, height standard deviation score (SDS) for chronological age (CA) or bone age (BA) and height at the start of treatment, stressing the importance of early diagnosis and treatment to prevent further loss of height $t^{3,4,6}$.

Another contributing factor might be

Reprint requests : Dr. De Muinck Keizer-Schrama S.M.P.F., Sophia Children's Hospital, P.O. Box 70029, 3000 LL Rotterdam, The Netherlands. that $\mathrm{GH}$ treatment shortens the duration of puberty and consequently the duration of the pubertal growth spurt. In a recent study in the United Kingdom the pubertal parameters of 134 children with isolated GH deficiency treated writh GH were evaluated retrospectively. The duration of puberty was significantly shorter compared with corresponding normal values for girls and boys'. Bourguignon and coworkers found a highly significant positive correlation between adult height and the height at the start of pubertal development ${ }^{8}$. Therefore attempts should be made to improve height before puberty starts. When puberty starts while the child is still very short we might consider to give gonadotropin-releasing hormone analogues in addition to $\mathrm{GH}$ treatment in order to postpone puberty and thereby improve final height.

In the past, because of the limited supply of pituitary derived $\mathrm{GH}$, the doses of $\mathrm{GH}$ and frequencies of administration were low and varied among the various groups in different countries. Some of the earlier results are shown in Table 1 . In the Netherlands, the initial weekly dosage of $\mathrm{GH}$ was approximately $8 \mathrm{IU}$ divided over two intramuscular (i.m.) injections. All 
TABLE 1. Height Velocities During Growth Hormone Treatment

\begin{tabular}{|c|c|c|c|c|c|c|c|c|}
\hline \multirow[t]{2}{*}{ Author } & \multicolumn{2}{|c|}{ GH dosage per week } & \multirow{2}{*}{$\begin{array}{l}\text { No. of } \\
\text { patients }\end{array}$} & \multicolumn{5}{|c|}{ Height velocity (cm/year, mean (SD) } \\
\hline & $\mathrm{IU}$ & frequency & & before & year 1 & year 2 & year 3 & year 4 \\
\hline $\begin{array}{l}\text { Trygstad9 } \\
1968\end{array}$ & $8-16$ & $1-2$ & 20 & 2.8 & 9.7 & $\begin{array}{l}5.8 \\
(n=13)\end{array}$ & $\begin{array}{l}5.3 \\
(n=9)\end{array}$ & $\begin{array}{l}5.0 \\
(n=6)\end{array}$ \\
\hline $\begin{array}{l}\text { Tanner }{ }^{10} \\
1971\end{array}$ & 20 & 2 & 35 & $3.1 \pm 0.2$ & $9.1 \pm 0.5$ & & & \\
\hline \multirow[t]{2}{*}{$\begin{array}{l}\text { Frasier }^{11} \\
1977\end{array}$} & $2.7 / \mathrm{m}^{2}$ b. $\mathrm{s}^{0}$ & 3 & 12 & $3.5 \pm 0.4$ & $6.4 \pm 0.4$ & $4.8 \pm 0.4$ & & $(n=9)$ \\
\hline & $5.4 / \mathrm{m}^{2} \mathrm{~b} . \mathrm{s}^{0}$ & 3 & 16 & $3.6 \pm 0.4$ & $7.3 \pm 0.4$ & $5.8 \pm 0.4$ & & $(n=14)$ \\
\hline $\begin{array}{l}\text { Ranke }^{2} \\
1979\end{array}$ & $8-12$ & $2-3$ & 36 & $\begin{array}{l}3.7 \pm 1.1 \\
(n=25)\end{array}$ & $\begin{array}{l}7.7 \pm 2.4 \\
(n=36)\end{array}$ & $\begin{array}{l}6.0 \pm 2.2 \\
(n=33)\end{array}$ & $\begin{array}{l}5.4 \pm 2.2 \\
(n=22)\end{array}$ & $\begin{array}{l}5.1 \pm 2.0 \\
(n=19)\end{array}$ \\
\hline $\begin{array}{l}\text { Verbeek }{ }^{12} \\
1979\end{array}$ & 8 & 2 & 38 & 3.1 & 7.9 & 6.1 & $\begin{array}{l}5.0 \\
(n=24)\end{array}$ & $\begin{array}{l}4.2 \\
(n=12)\end{array}$ \\
\hline
\end{tabular}

0 estimated from data given

patients received the same amount of $\mathrm{GH}$ irrespective of age, height, weight or body surface $e^{12}$. Most studies showed that after an initial period of supra normal growth ("catch-up") with GH therapy, growth velocity settles back to values close to normal for age.

\section{Recent Studies}

Therefore, it is reasonable to assume that not only diagnosis and treatment but also optimization of dosage and methods of administration of $\mathrm{GH}$ will improve final height. Several groups, in and outside Europe, showed a quantitative relationship between the $\mathrm{GH}$ dosage and the growth response to $\mathrm{GH}$ replacement ${ }^{13-16}$. However, others questioned such dose-response relationship ${ }^{17}$. Up to the mid-eighties the frequency of two, or three i.m. injections weekly was chosen based on clinical observations of the growth response. It was, however, a compromise between growth rate, the availability of $\mathrm{hGH}$ and the amount of $\mathrm{GH}$ in each ampoule and cost/benefit calculations. Studies in rats showed the importance for optimal growth with more frequent $\mathrm{GH}$ administration ${ }^{18-20}$. Moreover, GH is secreted in episodic bursts over both day and night in normally growing children and therefore at least daily administration appears to be more physiological.

Christiansen and co-workers showed that subcutaneous (s.c.) injections of $2 \mathrm{IU}$ $\mathrm{GH}$ per square meter body surface given daily in the evening to GHD children resulted in plasma GH concentrations, which approximated the average nocturnal plasma patterns of normal growing children ${ }^{21}$. Later on it was demonstrated that daily s.c. GH injections instead of twice or thrice weekly i.m. injections resulted in a higher growth rate at least in the first year of study 22,23 . Based upon these findings the currently used treatment schedule for GHD children in the Netherlands in $2 \mathrm{IU} \mathrm{hGH} / \mathrm{m}^{2}$ b.s./day ad- 
ministered s.c.

Multi-Centric Dose-Response Study

The availability of an almost unlimited supply of recombinant DNA-synthesized human GH enabled further studies on the dose-response relationship in GH treatment. In 1987 we started a collaborative multi-center dose response study in prepubertal GHD children in the Netherlands. The aims of the study were to assess the efficacy and safety of two different doses of authentic biosynthetic human growth hormone in children with GHD and to compare the effect of two doses GH on clinical, auxological and biochemical parameters. Two groups of prepubertal GHD children with isolated or multiple pituitary b-hGH hormone deficiencies were formed. Group I consisted of patients previously treated with b-hGH for at least one year and for at least half a year on fixed dosage $\left(12 \pi \mathrm{U} / \mathrm{m}^{2}\right.$ b.s./ week s.c.) i.e. transfer patients. Group II consisted of newly diagnosed GHD children. The patients of both groups were randomly assigned to treatment with either $2 \mathrm{IU}$ or $4 \mathrm{IU}$ biosynthetic $\mathrm{GH}$ per square metre bodysurface administered s.c. in a daily dosage. For children with multiple pituitary hormone deficiencies adequate replacement doses of thyroxine and/or hydrocortisone were used.

The results of the first two years of study are submitted for publication. The auxological findings can be summarized as follows :

(i) In previously treated prepubertal GHD patients the increase of the GH dosage up to $4 \mathrm{rU} / \mathrm{m}^{2}$ b.s./day s.c. resulted not only in a renewed catch-up growth in the first year of study but also in a sus- tained increase in height velocity (HV), HV SDS, height SDS and predicted adult height in the second year significantly higher than with $2 \mathrm{IU} / \mathrm{m}^{2}$. The advance in bone maturation was comparable for the two dosage groups.

(ii) In newly diagnosed GHD patients one year $\mathrm{GH}$ therapy with both $2 \mathrm{IU}$ and $4 \pi / \mathrm{m}^{2} /$ day s.c. resulted in a significant increase in HV, HV SDS and height SDS for CA and BA.

(iii) If not only the $\mathrm{GH}$ dosage but also the pretreatment maximal plasma $\mathrm{GH}$ value after pharmacological stimulation is taken into account, the higher dosage of $4 \mathrm{IU} / \mathrm{m}^{2}$ has a significant better effect on the growth response than $2 \pi / \mathrm{m}^{2}$.

(iv) The change of height SDS for BA compared with pretreatment was significantly higher with $4 \mathrm{IU}$ than with $2 \mathrm{IUGH} /$ $\mathrm{m}^{2}$ b.s./day. Although these first year results point to a better growth effect with 4 IU than with $2 \mathrm{IU}$, also in newly diagnosed GHD patients, the second and subsequent years of treatment have to be awaited to draw further conclusions.

\section{CONCLUSION}

It is obvious that the results published so far as well as the present preliminary data do not answer many questions regarding the optimal therapeutic regimen in $\mathrm{GH}$ deficiency. In particular, long-term follow-up must be organized to evaluate efficacy and safety of GH therapy not only in GHD but also for the "new" indications such as Turner syndrome, short stature without classical GH deficiency and chronic renal failure.

Finally the high expectations and the high costs of longterm GH treatment 
should receive full consideration.

\section{REFERENCES}

1. Raben MS. Treatment of a pituitary dwarf with human growth hormone. I Clin Endocrinol 1958; 18 : 901-903.

2. Ranke $M$, Weber $B$, Bierich JR. Long-term response to human growth hormone in 36 children with idiopathic growth hormone deficiency. Eur J Pediatr 1979; 132 : 221-238.

3. Burns EC, Tanner JM, Preece MA, Cameron $N$. Final height and pubertal development in 55 children with idiopathic growth hormone deficiency, treated for between 2 and 15 years with human growth hormone. Eur I Pediatr $1981 ; 137$ : 155-164.

4. Joss E, Zuppinger $K$, Schwarz HP, Roten $H$. Final height of patients with pituitary growth failure and changes in growth variables after long tern hormonal therapy. Pediatr Res 1983; $17: 676-679$.

5. Bundak R, Hindmarsh PC, Smith PJ, Brook CGD. Long-term auxologic effects of human growth hormone. J Pediatr 1988; 112 : 875-879.

6. Hibi I, Tanaka T and Committee for Treatment of Growth Hormone Deficient Children, Growth Science Foundation, Japan. Final height of patients with idiopathic growth hormone deficiency after long-term growth hormone treatment. Acta Endocrinol (Copenh) $1989 ; 120: 409.415$.

7. Darendeliler $F$, Hindmarsh PC, Brook CGD. Dose-respon se curves for treatment with biosynthetic human growth hormone. I Endocrinol 1390; $125: 311-316$.

8. Bourguignon JP, Vandeweghe $M$, Vanderschueren-Lodeweyckx $M$ et al. Pubertal growth and final height in hypopitiutary boys: A minor role of bone age at onset of puberty. JClin Endocrinol Metab 1986; $63: 376-$ 382.

9. Trygstad $O$. Human growth hormone and hypopituitary growth retardation. Acta Peadiatr Scand 1969; 58 : 407-419.

10. Talnner JM, Whitehouse RH, Hughes PCR, Vince FP. Effect of human growth hormone treatment for 1 to 7 years on growth of 100 children, with growth hormone deficiency, low birthweight, inherited smallness, Turner's syndrome, and other complaints. Arch Dis Child 1971; $46: 745-782$.
11. Frasier SD, Aceto $T$, Hayles $\mathrm{AB}$, Mikity VG. Collaborative study of the effect of human growth hormone in growth hormone deficiency : IV. Treatment with low doses of human growth hormone based on body weight. J Clin Endocrinol Metab 1977; 44 :22-31.

12. Verbeek JHAM, Steendijk R, Bot A, Van der Werff ten Bosch $\Pi$. Langdurige behandeling van hypofysaire groeistoornissen met menselijk groeihormoon; resultaten bij 38 Nederlandse kinderen. Ned Tijdschr Geneeskd 1979; $13: 510-520$.

13. Preece MA, Tanner IM, Whitehouse RH, Cameron $N$. Dose dependence of growth response to human growth hormone deficiency. J Clin Endocrinol Metab 1976; 43 : $477-483$.

14. Frasier SD, Costin G, Lippe BM et al. A doseresponse curve for human growth hormone. I Clin Endocrinol Metab 1981; 53 : 1213-1217.

15. Vicens-Calvet $E$, Vendrell $\mathrm{IM}$, Albisu $M$ et al. The dosage dependency of growth and maturity in growth hormone deficiency treated with human growth hormone. Acta Paediatr Scand 1984;73:120-126.

16. Job JC, Chaussain $J L$, Garnier $P$ et al. Doseresponse relationship in the treatment of hypopituitary children with human growth hormone : a retrospective survey. Acta Paediatr Scand 1987; 337 : 93-105.

17. Rosenbloom AL, Knuth CL Growth response in growth hormone-deficient patients to 0.06 $\mathrm{mg} / \mathrm{kg}$ compared with $0.10 \mathrm{mg} / \mathrm{kg}$ three time per week of biosynthetic growth hormone. Am J Dis Child 1989; 143 : 642-643.

18. Jansson JO, Albertsson-Wikland K, Eden $S$ et al. Effect of frequency of growth hormone administration on longitudinal bone growth and body weight in hypophysectomized rats. Acto Physiol Scand 1982; 114:261-265.

19. Jansson JO, Albertsson-Wikland K, Eden $S$ et al. Circumstantial evidence for a role of the secretory pattern of growth hormone in control of body growth. Acta Endocrinol 1982; 99 : 24-30.

20. Clark RG, Jansson JO, Isaksson O, Robinson ICAF. Intravenous growth hormone : growth responses to patterned infusions in hypophysectomized rats. J Endocrinol 1985; 104 : 53-61.

21. Sandahl Christiansen J, Orskov H, Binder C, 
Kastrup KW. Imitation of normal plasma growth hormone profile by subcutaneous administration of human growth hormone to growth hormone deficient children. Acta Endocrinol 1983; 102:6-10.

22. Kastrup KW, Sandahl Christiansen J, Koch Andersen J, Orskov $H$. Increased growth rate following transfer to daily s.c. administration from three weekly i.m. injections of hGh in growth hormone deficient children. Acta Endocrinol 1983; 104 : 148-152.

23. Albertsson-Wikland $\mathrm{K}$, Westphal $\mathrm{O}$, Westgren U. Daily subcutaneous administration of human growth hormone in growth hormone deficient children. Acta Paediatr Scand 1986; $75: 89-97$. 